Original Research Article

\title{
A study of the cost analysis of various oral antihypertensive drugs available in Indian market
}

\author{
Neelesh Arya $^{1}$, Shweta Agrawal ${ }^{2 *}$, Mehul Agrawal ${ }^{1}$
}

${ }^{1}$ Department of Pharmacology, Gandhi Medical college, Bhopal, Madhya Pradesh, India ${ }^{2}$ Department of Shalakya Tantra, Pt. K.L.S. Govt. (Auto.) Ayurvedic College and Hospital, Bhopal, Madhya Pradesh, India

Received: 29 May 2019

Revised: 29 June 2019

Accepted: 02 July 2019

\section{*Correspondence to:}

Dr. Shweta Agrawal,

Email: shwetaagrawal2@ gmail.com

Copyright: (C) the author(s), publisher and licensee Medip Academy. This is an openaccess article distributed under the terms of the Creative Commons Attribution NonCommercial License, which permits unrestricted noncommercial use, distribution, and reproduction in any medium, provided the original work is properly cited.

\begin{abstract}
Background: Hypertension is a serious global public health problem. It accounts for $10 \%$ of all deaths in India and is the leading non-communicable disease. Recent studies have shown that the prevalence of hypertension is $25 \%$ in urban and $10 \%$ in rural people in India. It exerts a substantial public health burden on cardiovascular health status and health care systems in India. Antihypertensive treatment effectively reduces hypertension related morbidity and mortality. The cost of medications has always been a barrier to effective treatment. The increasing prevalence of hypertension requires use of cost effective treatment for the effective management of the disease.

Methods: Cost of a particular drug (cost per 10 tablets) in the same strength and dosage forms being manufactured by different companies was obtained from Current Index of Medical Specialties, Jan-April 2019 and "Indian Drug Review" (IDR) September 2018. Difference between the maximum and minimum cost of the same drug manufactured by different pharmaceutical companies was calculated and percentage cost variation was calculated.

Results: The prices of a total of 24 drugs (15 single and 9 combination preparations), available in 59 different formulations were analysed. These 62 formulations are manufactured by different pharmaceutical companies.

Conclusions: The average percentage price variation of different brands of the same oral antihypertensive drug manufactured in India is very wide. The appraisal and management of marketing drugs should be directed toward maximizing the benefits of therapy and minimizing negative personal and economic consequences.
\end{abstract}

Keywords: Antihypertensive drugs, Cost analysis, Hypertension, Pharmacoeconomics

\section{INTRODUCTION}

Hypertension is one of the major chronic diseases resulting in high mortality and morbidity in today's world., ${ }^{1,2}$ Essential hypertension is considered the most important $\mathrm{CV}$ risk factor on the basis of its very high incidence and its direct, linear relationship with CV events. ${ }^{3,4}$ Evidence from large clinical trials now suggest that lowering blood pressure effectively prevents these adverse outcomes. ${ }^{5,6}$ Pharmaceutical Industry in India has grown with tremendous pace and Indian markets are flooded with a huge number of branded formulations with large difference in the manufacturing cost of drugs and their maximum retail price and the cost of different brands of the same formulation. This apart from creating confusion among innocent consumers, often allows them to be misled by unfair traders. ${ }^{7}$ High cost of medicines has economic implications for the patients. Prices of prescription can affect users, suppliers and most importantly payers in health care system. ${ }^{8}$ In fact, several studies have indicated that therapeutic compliance is influenced by drug prices. ${ }^{9}$ Thus; the cost of therapy may be a barrier in controlling high blood pressure and should be an important consideration in selecting antihypertensive medication. The prices of the different antihypertensive drugs vary, and price alone is only one factor which should 
be taken into account when considering drugs that should be reimbursed. ${ }^{10}$

India is still a developing country and majority of its population are middle income families or come from a poor socioeconomic background. According to the planning commission report $29.5 \%$ of Indians 1.21 billion people live below poverty line. ${ }^{11}$ With hypertension being very common in developing countries it becomes a huge burden on people living in lower socioeconomic strata to buy medicines especially if they have to be taken for prolonged periods of time. Cost analysis is a type of pharmacoeconomic evaluation in which comparison of costs of two or more alternative medication is made without regard to outcome. ${ }^{12,13}$

Hypertension is the most common modifiable risk factor for cardiovascular disease (CVD) and death; the increased risk associated with blood pressure (BP) elevation can be greatly reduced by treatment with antihypertensive drugs that lower both BP and related target organ damage. A total of 69 drugs in 15 different classes, many of which are also available in single pill combinations, have been approved for the treatment of hypertension in the United States. ${ }^{14}$ Various studies conducted in past show a wide variation in prices of cost of branded and generic versions of same drug. ${ }^{7,} 15$

Despite this plethora of treatment options, an estimated $10 \%$ to $15 \%$ of the general hypertensive population has resistant hypertension, defined as uncontrolled $\mathrm{BP}$ on $\geq 3$ antihypertensive drugs of different classes, including a non-potassium-sparing diuretic, at optimal doses, or requiring $\geq 4$ drugs to achieve control. ${ }^{15,16}$

In addition, $\approx 0.5 \%$ of hypertensive patients have refractory hypertension, defined as uncontrolled BP on $\geq 5$ drugs. ${ }^{17}$ Hence, the present study was undertaken to evaluate the price variation amongst the different brands of antihypertensives available in India.

\section{METHODS}

This study was an observational study planned to evaluate the price variation amongst the different brands of antihypertensive drugs available in Indian pharmaceutical market. Total duration of this study was 3 months. Cost of a particular drug (cost per 10 tablets) in the same strength and dosage forms being manufactured by different companies was obtained from "Current Index of Medical Specialties" Jan-April 2019 and "Indian Drug Review" (IDR) September 2018. The drugs being manufactured by only one company or being manufactured by different companies; however, in different strengths were excluded. Difference between the maximum and minimum cost of the same drug manufactured by different pharmaceutical companies was calculated. The prices of a total of 24 drugs (15 single and 9 combination preparations), available in 59 different formulations were analysed. Percentage cost variation ${ }^{10}$ was calculated by following statistical method:

\author{
Max cost - Min cost X 100 \\ $\%$ cost variation $=$ \\ Min cost
}

\section{RESULTS}

The prices of a total of 24 drugs (15 single and 9 combination preparations), available in 59 different formulations were analysed. These 59 formulations are manufactured by different pharmaceutical companies. Table 1 shows the price variation of a few commonly used antihypertensives used as a single drug therapy. Overall amlodipine $(5 \mathrm{mg})$ shows maximum price variation of $1128.57 \%$, while Olmesartan $(10 \mathrm{mg})$ shows minimum variation of $25.64 \%$.

The maximum and minimum percentage price variation respectively for CCBs: Amlodipine (5 mg) $1128.57 \%$ and nifedipine (5 mg) $36.36 \%$, ACE inhibitors: Enalapril (10 $\mathrm{mg}) 394.67 \%$ and ramipril (10 $\mathrm{mg})$ 92.21\%, ARBs: Telmisartan (20 mg) $288.33 \%$ and Olmesartan (10 mg) $25.64 \%$, beta blockers: Atenolol $(12.5 \mathrm{mg}) 683.53 \%$ and nebivolol ( $5 \mathrm{mg}$ ) $63.76 \%$. Table 2 shows price variation in combination of drugs were out of 10 combination therapies commonly used drugs like amlodipine+atenolol $(5+50$ $\mathrm{mg}$ ) combination shows maximum variation up to $673.79 \%$, telmisartan+hydrochlorothiazide $(40+12.5 \mathrm{mg})$ and $(80+12.5 \mathrm{mg}) 293.85 \%$ and $288.74 \%$, respectively, losartan+hydrochlorothiazide $(50+12.5 \mathrm{mg}) \quad 384.62 \%$, atenolol+hydrochlorothiazide $\quad 451.81 \% \quad$ and amlodipine+losartan $(5+50 \mathrm{mg})$ shows variation of $284.61 \%$.

\section{DISCUSSION}

Appropriate antihypertensive drug therapy is important as the prevalence of hypertension has risen dramatically in last three decades. ${ }^{18}$

Any deviation from evidence-based guidelines in hypertension treatment contributes to the high cost of medications and creates difficulties in providing affordable prescription drugs. ${ }^{19}$

Indian market is predominantly a branded generic market i.e. more than one company sells a particular drug under different brand names apart from the innovator company. Hence, the number of pharmaceutical products available in the market also is very high in the range of 60,000-70,000 products. This situation has led to greater price variation among drugs marketed. ${ }^{20}$

Very few studies are available in Indian scenario, which compare the cost of drugs of different brands. Therefore, we decided to carry out the study which compares the cost of different brands of drug of one of the most common disorder.

The drug prices available in CIIMS and IDR were compared as they are readily available source of drug 
information and are updated regularly. Drugs used in the management of hypertension were selected as it is one of the major causes of morbidity and mortality, and the treatment requires continuous prescription drug use.

Table 1: Cost variation of single drug therapy.

\begin{tabular}{|c|c|c|c|c|c|c|}
\hline Drug & Formulations & Doses & $\begin{array}{l}\text { Manufacturing } \\
\text { companies }\end{array}$ & $\begin{array}{l}\text { Minimum cost } \\
\text { (Rs) }\end{array}$ & $\begin{array}{l}\text { Maximum cost } \\
\text { (Rs) }\end{array}$ & $\begin{array}{l}\% \text { price } \\
\text { variation }\end{array}$ \\
\hline \multicolumn{7}{|c|}{ Calcium channel blockers } \\
\hline \multirow{3}{*}{ Amlodipine } & \multirow{3}{*}{3} & 2.5 & 36 & 4.8 & 44 & 816.67 \\
\hline & & 5 & 58 & 7 & 86 & 1128.57 \\
\hline & & 10 & 30 & 13.6 & 114.52 & 742.06 \\
\hline \multirow{3}{*}{ Nifedipine } & \multirow{3}{*}{3} & 5 & 2 & 6.82 & 9.3 & 36.36 \\
\hline & & 10 & 3 & 6.01 & 15.22 & 153.24 \\
\hline & & 20 & 3 & 7.5 & 12.94 & 72.53 \\
\hline \multirow{4}{*}{ Diltiazem } & \multirow{4}{*}{4} & 30 & 13 & 14.75 & 36 & 144.06 \\
\hline & & 60 & 10 & 28.5 & 64 & 124.56 \\
\hline & & 90 & 2 & 46.016 & 80.92 & 75.85 \\
\hline & & 120 & 3 & 57.68 & 88.5 & 54.43 \\
\hline \multicolumn{7}{|l|}{ Beta blockers } \\
\hline \multirow{4}{*}{ Atenolol } & \multirow{4}{*}{4} & 12.5 & 4 & 2 & 15.67 & 683.53 \\
\hline & & 25 & 29 & 4.14 & 23.85 & 476.1 \\
\hline & & 50 & 41 & 5.71 & 37.92 & 564.1 \\
\hline & & 100 & 19 & 19.6 & 56.57 & 188.6 \\
\hline \multirow{3}{*}{ Metoprolol } & \multirow{3}{*}{3} & 25 & 9 & 10.8 & 41.6 & 285.185 \\
\hline & & 50 & 9 & 17 & 59.9 & 252.35 \\
\hline & & 100 & 4 & 54 & 90.6 & 67.78 \\
\hline \multirow{2}{*}{ Nebivolol } & \multirow{2}{*}{2} & 2.5 & 15 & 15.8 & 48 & 203.79 \\
\hline & & 5 & 20 & 46.6 & 76.31 & 63.76 \\
\hline \multirow{4}{*}{ Carvedilol } & \multirow{4}{*}{4} & 3.125 & 17 & 7 & 35 & 400 \\
\hline & & 6.25 & 14 & 12 & 47 & 291.67 \\
\hline & & 12.5 & 17 & 22 & 60 & 172.73 \\
\hline & & 25 & 12 & 42 & 91.3 & 117.38 \\
\hline \multicolumn{7}{|l|}{ ACE inhibitors } \\
\hline \multirow{3}{*}{ Enalapril } & \multirow{3}{*}{3} & 2.5 & 20 & 6 & 22.6 & 276.67 \\
\hline & & 5 & 20 & 9 & 36.84 & 309.33 \\
\hline & & 10 & 17 & 12 & 59.36 & 394.67 \\
\hline \multirow{4}{*}{ Ramipril } & \multirow{4}{*}{4} & 1.25 & 7 & 12.5 & 40.77 & 226.16 \\
\hline & & 2.5 & 22 & 27 & 73.53 & 172.33 \\
\hline & & 5 & 21 & 49 & 123.9 & 152.86 \\
\hline & & 10 & 8 & 92.8 & 179.3 & 92.21 \\
\hline \multicolumn{7}{|l|}{ ARBs } \\
\hline Losartan & 2 & 25 & 48 & 12 & 45.1 & 275.83 \\
\hline Losartan & 2 & 50 & 57 & 24.5 & 93.85 & 283.06 \\
\hline & & 20 & 32 & 18 & 69.9 & 288.33 \\
\hline Telmisartan & 3 & 40 & 43 & 28 & 89 & 217.86 \\
\hline & & 80 & 15 & 89 & 160 & 79.77 \\
\hline & & 10 & 6 & 39 & 49 & 25.64 \\
\hline Olmesartan & 3 & 20 & 13 & 49 & 135 & 175.51 \\
\hline & & 40 & 12 & 79 & 230 & 191.13 \\
\hline Diuretics & & & & & & \\
\hline Hydrochlorthiazide & 2 & 12.5 & 23 & 25 & 104 & 316 \\
\hline Furosemide & 2 & 20 & 25 & 18 & 42 & 133.33 \\
\hline Spironolactone & 2 & 25 & 31 & 16 & 51 & 218.75 \\
\hline
\end{tabular}


Table 2: Cost variation of combination therapy.

\begin{tabular}{|c|c|c|c|c|c|c|}
\hline Drug & Formulations & $\begin{array}{l}\text { Doses } \\
(\mathrm{mg})\end{array}$ & $\begin{array}{l}\text { Manufacturing } \\
\text { companies }\end{array}$ & $\begin{array}{l}\text { Minimum } \\
\text { cost }(\mathbf{R s})\end{array}$ & $\begin{array}{l}\text { Maximum } \\
\text { cost }(\mathbf{R s})\end{array}$ & $\begin{array}{l}\% \text { price } \\
\text { variation }\end{array}$ \\
\hline \multirow{2}{*}{ Amlodipine+atenolol } & \multirow{2}{*}{2} & $5+50$ & 72 & 10.3 & 79.7 & 673.79 \\
\hline & & $5+25$ & 9 & 11 & 35.1 & 219.09 \\
\hline \multirow{2}{*}{ Amlodipine+losartan } & \multirow{2}{*}{2} & $5+50$ & 18 & 20.8 & 73.35 & 284.61 \\
\hline & & $5+25$ & 3 & 32 & 39 & 21.88 \\
\hline Amlodipine+lisinopril & 1 & $5+5$ & 19 & 26 & 75 & 188.46 \\
\hline \multirow{2}{*}{ Amlodipine+telmisartan } & \multirow{2}{*}{2} & $5+40$ & 13 & 63 & 97 & 107.94 \\
\hline & & $5+80$ & 3 & 84 & 145 & 82.5 \\
\hline \multirow{2}{*}{$\begin{array}{l}\text { Telmisartan+hydrochloro } \\
\text { thiazide }\end{array}$} & \multirow{2}{*}{2} & $40+12.5$ & 44 & 24.7 & 97.28 & 293.85 \\
\hline & & $80+12.5$ & 8 & 37.3 & 145 & 288.74 \\
\hline \multirow{2}{*}{$\begin{array}{l}\text { Losartan+hydrochlorothi } \\
\text { azide }\end{array}$} & \multirow{2}{*}{2} & $50+12.5$ & 48 & 26 & 126 & 384.62 \\
\hline & & $25+12.5$ & 4 & 28.5 & 50 & 76.78 \\
\hline \multirow{2}{*}{$\begin{array}{l}\text { Enalapril+hydrochlorothi } \\
\text { azide }\end{array}$} & \multirow{2}{*}{2} & $10+2.5$ & 5 & 28 & 62 & 121.43 \\
\hline & & $5+12.5$ & 2 & 25 & 31.4 & 25.6 \\
\hline \multirow{2}{*}{$\begin{array}{l}\text { Ramipril+hydrochlorothi } \\
\text { azide }\end{array}$} & \multirow{2}{*}{2} & $5+12.5$ & 3 & 55 & 136 & 147.27 \\
\hline & & $2.5+12.5$ & 13 & 39.5 & 76.5 & 93.67 \\
\hline \multirow{2}{*}{$\begin{array}{l}\text { Metoprolol+hydrochlorot } \\
\text { hiazide }\end{array}$} & \multirow{2}{*}{2} & $100+12.5$ & 2 & 27.15 & 29.71 & 9.43 \\
\hline & & $50+15$ & 2 & 22.7 & 57 & 151.1 \\
\hline
\end{tabular}

Study findings reveal that the prices of most of the antihypertensive brands have percentage price variation above $100 \%$, which is not acceptable situation for patients. Of 32 drugs studied, most of which are commonly prescribed, percentage price variation is very wide leading to unfair burden on the consumer. Similar findings were shown by Karve AV et al. ${ }^{10}$

The evidence from pharmacoeconomic evaluations can provide valuable information for decision makers in setting public health priorities. Many pharmacoeconomic studies of antihypertensive medicines conducted in recent years have found control of hypertension to be cost effective. Several systematic reviews of these studies also have been published, but their focus has been on a specific medicine, such as irbesartan, or medicine class, such as ACEIs or ARBs. ${ }^{21,22}$ Thus, no comprehensive review has been conducted for studies across all anti-hypertensive medicine classes. The objectives are to systematically review all pharmacoeconomic evaluations of antihypertensive medicines and summarize the cost effectiveness of these medicines.

Economic evaluation evidence for major health policy and public health interventions, such as hypertension treatment, is extremely valuable for demonstrating whether expenditure by organized health systems on these interventions represents "money well spent." It can also help to justify whether more or fewer of the scarce healthcare resources should be allocated for this purpose. In principal, for a chronic disease like hypertension, economic evaluations are nowadays performed by adopting a wide timeframe for the analysis, in order to include all future aspects (costs and outcomes) of the disease/intervention under survey. However, to complete the economic evaluation data surrounding treatment, short term economic evaluations with clinical endpoints are necessary although sparsely reported in the literature..$^{23,24}$

\section{CONCLUSION}

The average percentage price variation of different brands of the same oral antihypertensive drug manufactured in India is very wide. The appraisal and management of marketing drugs should be directed toward maximizing the benefits of therapy and minimizing negative personal and economic consequences.

\section{Funding: No funding sources \\ Conflict of interest: None declared \\ Ethical approval: Not required}

\section{REFERENCES}

1. Collins R, Peto R, MacMahon S, Godwin J, Qizilbash $\mathrm{N}$, Hebert P, Eberlein KA, et al. Blood pressure, stroke, and coronary heart disease: part 2, short-term reductions in blood pressure: overview of randomised drug trials in their epidemiological context. Lancet. 1990;335(8693):827-38.

2. Hansson L. The benefits of lowering elevated blood pressure: a critical review of studies of cardiovascular morbidity and mortality in hypertension. J Hypertens. 1996,14(5),537-44.

3. Ezzati M, Lopez AD, Rodgers A, Vander Hoorn S, Murray CJ. Comparative Risk Assessment Collaborating Group. Selected major risk factors and global and regional burden of disease. Lancet. 2002;360(9343):1347-60. 
4. Lewington S, Clarke R, Qizilbash N, et al. Age specific relevance of usual blood pressure to vascular mortality; a met-analysis of individual data for one million adults in 61 prospective studies. Lancet 2002;360(9349):1903-13

5. Neal B. Blood Pressure Lowering Treatment Trialists' Collaboration. Effects of ACE inhibitors, calcium antagonists, and other blood-pressure-lowering drugs: results of prospectively designed overviews of randomised trials. Blood Pressure Lowering Treatment Trialists' Collaboration. Lancet. 2000;356(9246):1955-64.

6. Staessen JA, Wang JG, Thijs L. Cardiovascular protection and blood pressure reduction: a metaanalysis. Lancet. 2001, 358, 1305-15.

7. Das SC, Mandal M, Mandal SC. A critical study on availability and price variation between different brands: Impact on access to medicines. Ind J Pharm Sci. 2007;69(1):160-3.

8. Patel D, Thiyagu R, Surulivelrajan M, Patel H, Pandey S. Price variability among the oral antibiotics available in a South Indian Tertiary Care Hospital. J Clin Diagn Res. 2009;3(6):1871-5.

9. Shankar PR, Subish P, Mishra P, Lalit M. Ambiguous pricing of Nepalese medicines. $\mathrm{J}$ Inst Med. 2006;28(3):35-8.

10. Karve AV, Chattar KB. Cost analysis study of oral antihypertensive agents available in Indian market. Int J Basic Clin Pharmacol. 2014;3(3):479-83.

11. Planning Commission Report. Government of India 2014. Available at: http://www.planningcommission.nic.in/reports/genre p/por_rep0707.pdf.

12. Ahuja J, Gupta M, Gupta AK, Kohli K. Pharmacoeconomics. Natl Med J India. 2004;17(2):80-3.

13. Sanchez LS. Pharmacoeconomics: Principles, methods and applications. In: Dipiro JT, Talbert RL, Yee GC, Matzke GR, Wells BG, Posey ML. Eds. Pharmacotherapy: A pathophysiological approach. $7^{\text {th }}$ ed. New York, NY: McGraw-Hill; 2008:179-201.

14. Food and Drug Administration and the Department of Health and Human Services. Notice. Guidance for Industry on Hypertension Indication: Drug Labeling for Cardiovascular Outcome Claims; Available at: http://www.fda.gov/downloads/Drugs/.../Guidances/u cm075072.pdf). Accessed 15 March 2011.
15. Persell SD. Prevalence of resistant hypertension in the United States, 2003-2008. Hypertension. 2011;57(6):1076-80.

16. Sim JJ, Bhandari SK, Shi J, Liu IL, Calhoun DA, McGlynn EA, et al. Characteristics of resistant hypertension in a large, ethnically diverse hypertension population of an integrated health system. Elsevier. Mayo Clin Proc. 2013;88(10):10991107.

17. Calhoun DA, Booth III JN, Oparil S, Irvin MR, Shimbo D, Lackland DT, et al. Refractory hypertension: determination of prevalence, risk factors, and comorbidities in a large, population-based cohort. Hypertension. 2014;63(3):451-8.

18. $\mathrm{R}$ Gupta. Trends in hypertension epidemiology in India. J Hum Hypertens. 2004;18(2):73-78.

19. Fischer MA, Avorn J. Economic implications of evidence-based prescribing for hypertension: can better care cost less? JAMA. 2004;291(15):1850-56.

20. Thomas M. Rational drug use and essential drug concept. In: Parthasarthi G, Nyfort Hasen K, editors. A Textbook of Clinical Pharmacy Practice. $1^{\text {st }}$ ed. Himayatnagar, Hyderabad: Orient Longman; 2004:7273.

21. Gialama F, Maniadakis N. Comprehensive overview: efficacy, tolerability, and cost-effectiveness of irbesartan. Vasc Health Risk Manag. 2013;9:575-592.

22. Huang Y, Zhou Q, Haaijer-Ruskamp FM, Postma MJ. Economic evaluations of angiotensin-converting enzyme inhibitors and angiotensin II receptor blockers in type 2 diabetic nephropathy: a systematic review. BMC Nephrol. 2014;15(1):15.

23. Miller L, Wade R, Dai D, et al. Economic evaluation of four angiotensin II receptor blockers in the treatment of hypertension. Curr Med Res Opin. 2010;26(6):1307- 20.

24. Chen R, Lapuerta P. Cost per millimeter of mercury lowering is a measure of economic value for antihypertensive agents. Curr Hypertens Rep. 2000;2(6):525-9.

Cite this article as: Arya N, Agrawal S, Agrawal M. A study of the cost analysis of various oral antihypertensive drugs available in Indian market. Int J Basic Clin Pharmacol 2019;8:1850-4. 